\title{
1950年代における大蔵省の金融機関行政と金融検査
}

一経常収支率規制と組織的管理体制構築問題を巡って—

白鳥圭志

1 問題の所在

(1) 問題の所在

本稿は，地方銀行と相互銀行を主たる対象にして，1950年代において大蔵省金融検査官が認 識した金融機関の組織的管理体制構築に関する問題を検討する。本問題の検討を通じた，行政 指導の方向性とその改善への効果も含む, 組織的管理体制の構築を巡る検査と行政指導の特質 の明確化を，本稿の課題とする。その際，金融検査官の業務の前提になる，通牒・通達に示さ れる大蔵省の金融機関に対する行政指導方針，特に経常収支率規制関係のあり方や，これと実 際の検査と行政指導との関連も併せて再検討する。

既に戦前期の時点で，大蔵省銀行検查官たちは，行政指導の対象となる個別金融機関の経営 情報を入手するという意味で規制体系実施上の要となる検查と行政指導を通じて, 銀行経営, 特に地方銀行経営にルールと手続きを重視した「近代官僚制的」な組織的管理体制(1)を構築す る必要性を感じていた(2)。この考えに基づき, 確認できる限りで, 第一次世界大戦期以降の検 査と指導の過程において，単なるプルーデンスには止まらない，事務処理規定などの内規の整 備や組織的な管理体制の構築を促した。しかしながら，このような指導は不十分なままに終わ つた。その後の第 2 次世界大戦期における銀行合同過程でも, 経営規模の拡大がもたらされた ものの，合同の急速さゆえに，合併参加銀行の役員間対立の残存も含めて，規模拡大に見合っ た組織的な管理体制の構築は殆ど未実現なままに終わった。これに加えて, 戦後の激しい労働 運動の結果，十分な合理化が進展しなかった。このような状況で，各金融機関経営は，本稿の 対象である1950年代の歴史的前提条件となる戦後復興期を迎えた。

ところで，戦後日本の金融行政の重要特徵が，中小企業金融機関の保護と金融機関破綻回避 を主眼とする，いわゆる護送船団方式にあることは周知のとおりである。先行研究では(3)，そ の特徵として「諸比率指導」という数量的性格を強調する一方で, 他方では指導方法として, 銀行局長による業態別業界団体宛を中心とする通皤・通達，個別銀行には銀行局長からの口頭 
伝達および検査結果に基づく示達を指摘した。その際，行政指導が効力を発揮した要因とし て, 周知の大蔵省当局による許認可行政を通じた利益の供与という誘因の存在を単純なゲーム 理論に基づき整理した。その上で，50年代前半期を健全経営への誘導という課題を重視した時 期，同後半を「金融正常化」への誘導を重視した時期と位置づけた。

しかしながら，大蔵省が，通牒・通達を通じて各金融機関に提示した「諸比率」達成のため に，銀行の経営管理体制に関わる問題で，どのような具体的改善措置を求め，かつ，指導した のか，という点まで踏み込んだ検討はされなかった。後述のように，この問題は，通牒・通達 の内容が検査の前提となる大蔵省の方針を示す以上，当該期における大蔵省金融検査の特質を 考える上でも重要である。さらに, 上記の誘因の効力がもっぱら結果のみから導出されている が，その過程において何の問題も無かったかどうかは疑問である。仮に問題が生じていたとす れば，どのような手段でこれを解決したのかが問われる必要がある。このほか，戦前来の金融 機関の組織的管理体制の構築を巡る検査と行政指導の歴史的な文脈の中に，1950年代の検査と 行政指導のあり方を十分に位置づけてもいない。これらの諸点を踏まえて分析を深化させなけ れば，当該期における検査と指導を通じた金融機関経営の在り方の歴史的変化の意義やその大 きさを十分に理解することはできない。

以上の限界を踏まえて, 本稿では第一の課題を, 上記の諸問題の検討を通じた，大蔵省の行 政指導の特質の明確化に設定する。その際, 特に焦点を経常収支率規制に絞る。このほか「諸 比率指導」と検查との関連も重視する。特に, 経常収支比率に関する指導は, 比率の提示に止 まり，金融機関内部に直接に立ち入った指導は行われなかったとされている。したがって，こ の点の吟味が重要な焦点のひとつとなる。なお, 先行研究では, 50年代における行政指導のあ り方を二つの時期に区分している。しかし，そこでは狭く銀行経営ないし金融の問題のみが取 り扱われており，借手である企業や産業との関係は考慮外であった。本稿では，このような限 界を考虑の上で検討する。

第二の検討課題は，検查を通じた組織管理（内部統制）体制構築面での指導の特質の明確化 である。先行研究では, 「直接的・個別的」検査・指導の主流化が指摘されている。しかしな がら，実際に金融機関に直接立ち入った検査官が，その業務を通じて銀行経営に対して抱いた 認識と, 改善指導の方向性の特徵は不問に付された。しかし, 最近の戦前期についての銀行行 政・銀行検查研究で明確化されたように(4), 日本の場合, 金融機関検査と指導は, 資産査定に 代表される一般的なプルーデンス政策を中心にしつつも, 不正も含む情実的経営阻止の観点か ら，ルールと手続に基づく計画的かつ「近代官僚制的」(5)な経営管理体制構築へ誘導すること も重視した点に特徵があった。50年代も, この限りでは戦前期と同様であり, 後述の検査は勿 論のこと, それ以外でも通牒・通達に示された「諸比率」是正についての要求との関連で, 経 営の計画化, 特に経営管理面の充実, 研修・教育による行員養成など, 組織的経営管理体制の 充実・強化による合理化を促していた。さらに(6)，検查部作成の解説書には「経理・記録その 
他事務処理」「買紙及び報告書要旨の使用法」「機密の部」における「役職員」に関する検査 項目と解説や，「銀行に対する諸資料の作成依頼」の中に「経理・記録その他事務処理に関す る設問」項目が盛り込まれており，大蔵省もこの点をプルーデンスと並ぶ，重要な柱のひとつ と位置づけていた $\left(52\right.$ 年度史料，413頁 $\left.{ }^{(7)}\right)$ 。

もっとも，現状では戦後の検査，特に資産査定関係を中心とするプルーデンスについての内 部史料の入手と利用が極めて困難である。それゆえ，検査の重要な柱である不良債権処理に関 わる行政指導や，指導全体の効果の検討は断念せざるを得なかった。この点に関しては，管見 の限り，一事例が判明するのみである ${ }^{(8)}$ 。その際，大蔵省は当該金融機関の不良債権の查定と 処理にあたり，一挙に償却すべきとの示達を出した。もっとも，当該金融機関は経営体力との 関係から，複数年かけた償却方針を答申し，大蔵省もこれを尊重して不良債権処理を促したと いう。被検査銀行の意向を尊重した点は戦前期と同様であった。以上の事実しか判明しない点 は，本稿の重大な限界である。しかし，当該期は，高度成長期という，都市銀行経営者をして 銀行経営を摇るがすような「不良債権が出なかった」と言わせる時期であり(9)，この限界は致 命的ではなかろう。

\section{（2） 1950年代を取扱う意義}

これに加えて，特に地方銀行以下の業態に顕著であるが，内部管理体制整備が「全国的な流 れでもあった」(10) (傍点は引用者。以下，同様。省略）との地方銀行関係者の回顧や，地方銀 行・相互銀行の業界団体の動き（表 1 ）に見られるように, 当該期は各業態ともに, 経営環境 の変化・業容拡大を背景に，計画的かつ「近代官僚制的」な経営管理体制の構築に向けて，業 界団体を中心に状況改善に努めた時期でもあった(11)。表 2 には，すべてではないが，閲覧で きた少なからぬ数の地方銀行，相互銀行の年史をもとにして，組織整備の進展状況に関する幾 つかの指標を示した。各行の年史には，必ずしも摘要闌に示した全項目についての記載がある わけではない。このような史料上の限界ゆえに，本表はあくまで大まかな傾向を示すに過ぎな い。それでも, 本表から, 既に49年以前の段階で地方銀行については, 管理部門の独立と強化 への動きを示す本部組織と本店営業部の分離や，検査部門の設置が進展していたものの，それ 以外の点では相互銀行も含めて，「近代官僚制」的組織の重要特徴である事務処理手続きの形 式合理化（規程の整備）の着手や，業務内容を検査する部門（検査部門），あるいは「近代的 経営の本質」とされる経営の計画化（長期経営計画の導入）とその実施のための関連部門（企 画部門）の設置が1950年代を通じて進展していたことが確認される(12)。原史料によれば，特 に50年代後半における「近代的経営」の到達点としての計画化の動きは，表示数以外の銀行に ついては60年代以降に実現する。この意味で，50年代は，金融機関の「近代的経営」到達への 最後の動きが始まった重要な局面だった。次にこの動きの背景である。幾つかの年史によれ ば，1950年代，特に半ば以降，朝鮮特需ブームの消滅による経済停滞の影響や，大衆化の本格 
経営史学 第 43 巻第 4 号

表 1 1950年代における地方銀行・相互銀行の業界団体の「経営近代化」への動き

\begin{tabular}{|c|c|}
\hline 開催時期 & 内容 \\
\hline \multicolumn{2}{|r|}{ 地方銀行 } \\
\hline 1950年 2 月 & 地方銀行職員の教育機関創設について例会での審議開始。 \\
\hline 6 月 & $\begin{array}{l}\text { 「銀行経営および銀行検査に関する研究会」開催。 } \\
\text { 銀行実務叢書刊行開始。 }\end{array}$ \\
\hline 1951年 4 月 & 地方銀行職員の研修を協会事業としての実施を決定。 \\
\hline 1952年 4 月 & 研究寮を設置。 \\
\hline 1953年 1 月 & 銀行叢書刊行開始。 \\
\hline 2 月 & 調整勘定中間処理研究会開催。 \\
\hline 8 月 & 審議担当者会議開催。 \\
\hline 1954年 6 月 & 検査方式委員会設置。 \\
\hline 12 月 & 『銀行の検査方式』を取りまとめ, 刊行。 \\
\hline 1955年 3 月 & 検査方式研究会開催。 \\
\hline 3 月 & 銀行経理に関する臨時専門委員会設置。 \\
\hline 1956年 3 月 & 合理化推進特別委員会設置。 \\
\hline 4 月 & 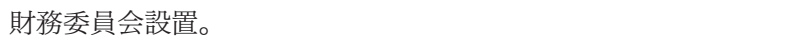 \\
\hline 8 月 & 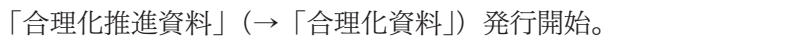 \\
\hline 9 月 & 第 1 回支店長講座実施。 \\
\hline 1957年 6 月 & 代理業務委員会設置。 \\
\hline 8 月 & 第 1 回得意先掛指導員訓練講座開催。 \\
\hline 9 月 & 合理化委員会設置。 \\
\hline 12 月 & 合理化第 1 専門委員会，同第 2 専門委員会設置。 \\
\hline 1958年 4 月 & 得意先掛訓練講座マニュアル作成。 \\
\hline 5 月 & 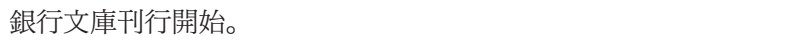 \\
\hline 7 月 & 第 1 回経営研究会（（役員経営研究会）実施。 \\
\hline 9 月 & 空口対応訓練マニュアル，同シート作成。 \\
\hline 10 月 & 合理化第1専門委員会「地方銀行の予算統制方式」を取りまとめ。 \\
\hline 1959年 3 月 & 合理化第3専門委員会 ( $\rightarrow$ 機械化專門委員会設置)。 \\
\hline 5 月 & 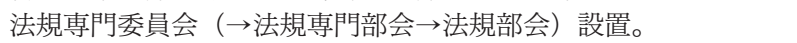 \\
\hline 10月 & 為替業務部会打合会開催。 \\
\hline \multicolumn{2}{|r|}{ 相互銀行 } \\
\hline 1951年 7 月 & 相互銀行実務講習会開催。 \\
\hline 12 月 & 『相互銀行実務講習録』全 3 巻を刊行。 \\
\hline 1952年10月 & 第 1 回相互銀行珠算競技会開催。 \\
\hline 1953年 2 月 & 第 2 回相互銀行実務講習会開催。 \\
\hline 6 月 & 第 3 回相互銀行実務講習会開催。 \\
\hline 12 月 & 第 2 回『相互銀行実務講習録』全 5 巻を刊行。 \\
\hline 1954年 2 月 & 預金掛金実務講習会開催。 \\
\hline 10 月 & 貸付事務講習会開催。 \\
\hline 1955年11月 & 実務講習会開催。 \\
\hline 1956年9月 & 研究会掛金表改定問題大綱作成。 \\
\hline 10 月 & セールスマン講習会開催。 \\
\hline 1957年 2 月 & 第 1 回演習講座開催。 \\
\hline 1958年 6 月 & $\begin{array}{l}\text { 「貯蓄の集い」開催。 } \\
\text { 経営管理講習会開催。 }\end{array}$ \\
\hline 10月 & 労務講習会開催。 \\
\hline 11月 & 統計調査講習会開催。 \\
\hline 1959年 6 月 & 中小企業診断員養成講座開催。 \\
\hline 8 月 & 相互銀行経営研修会（第 1 回）開催。 \\
\hline
\end{tabular}

出所：『全国地方銀行協会50年史』(同協会，1988年）付録年表，『相互銀行史』

付属年表（相互銀行協会，1971年）より作成。 
表 2 経営組織整備の状況

\begin{tabular}{|l|c|c|c|c|c|c|}
\hline \multirow{2}{*}{ 摘要/年代 } & \multicolumn{2}{|c|}{1949 年以前 } & \multicolumn{2}{|c|}{1950 54年 } & \multicolumn{2}{|c|}{$1955 \sim 60$ 年 } \\
\cline { 2 - 7 } & 地方銀行 & $\begin{array}{c}\text { 相互銀行 } \\
\text { (無尽) }\end{array}$ & 地方銀行 & 相互銀行 & 地方銀行 & 相互銀行 \\
\hline $\begin{array}{l}\text { 本部組織と本店営業 } \\
\text { 部の分離 }\end{array}$ & 18 & 4 & 14 & 23 & 3 & 2 \\
\hline $\begin{array}{l}\text { 事務処理規程整備へ } \\
\text { の着手 }\end{array}$ & 2 & 0 & 21 & 22 & 9 & 3 \\
\hline 企画部門の設置 & 5 & 0 & 8 & 7 & 12 & 8 \\
\hline 検查部門の設置 & 18 & 3 & 16 & 20 & 4 & 4 \\
\hline 長期総合計画の導入 & 0 & 0 & 3 & 1 & 9 & 11 \\
\hline
\end{tabular}

出所）各行『年史』により作成。

注 1 ）長期総合計画については開始年次を基準に集計。原史料によれば，事務処理規程は，着手 後, 通例, 少なくとも数年はかかる。

注 2 ）企画・検査の両部門の設置は独立の部・課化した時点のものを集計した。ある組織の下部組 織である場合(例えば部の中の課) は集計対象にしていない。独立のセクション化が両部門が 重視されたことを意味すると考えたからである。

注 3 ) 対象銀行名は次のとおり。

地方銀行：千葉，常陽，青森，第四，大分，四国，足利，伊予，秋田，静岡，十六，横浜，岩 手，百十四，京都，山口，広島，八十二，泉州，千葉興業，池田，東京都民，清水，福井，鹿 児島，琉球，北越，関東，駿河，東邦，佐賀，羽後，山陰合同，山梨中央，武蔵野，福岡，山 形, 北海道, 庄内, 沖縄, 宮崎, 南都, 三重。

相互銀行：西日本，東京，九州，兵庫，神奈川，北洋，秋田，福徳，近畿，殖産，名古屋，富 山，日本，広島，大光，大阪，徳陽，中部，高知，弘前，旭，阪神，松江，大東，正金，沖 縄，栃木，第三，山口，大生，肥後，国民，名古屋。

注 4 ） 1955 ・60年の地方銀行，相互銀行数はそれぞれ65行と64行，71行と72行 (『昭和財政史 終 戦から講和まで』第19巻，東洋経済新報社，1978年)。

化に伴う事務量の増加もあり，各銀行は合理化の必要性を認識したという(13)。このことが, 上記の「全国的流れ」の背景であった。この動きに対する検査官の認識や指導の方向性やその 効果の検討は，両大戦間期における金融危機下とは異なり，資産内容=経営健全性の問題が相 対的に後景に退く時期だけに重要であろう(14)。

その際，本稿では史料として若干の個別銀行の内部史料や業界団体史料のほか，主に『銀行 局金融年報』所載の検査報告を用いる。同史料は，業態面でも金融機関数面でもカヴァリッジ が広く(後述)，かつ，逐一引用はしないが，基本的に同一業態内での検查対象行の規模のバラ ンスも良いと判断される(15)。特に，本史料は，金融機関経営の抱える管理上の問題点と改善 の方向性の指摘を主眼としており，上記の課題に応えるには適切な内容をもつ。もっとも，そ の記述には，特定の金融機関を論じたと判断される部分と，各金融機関についての記述と判断 される部分が存在する。前者と判断されるものは，金融機関名も含めて，可能な限りその旨を 明示し，後者の場合も同様に取扱う。

本稿では，史料の制約上，地方銀行を中心とする普通銀行と相互銀行が主要な検討対象にな る(16)。これ以外の業態は，少なくとも，50年代においては，保険業・労働金庫を除く他業態 は，恒常的に検查報告が史料に残らない。信用金庫については，検查の受け手側の状況が分か 


\section{経営史学 第 43 巻第 4 号}

る史料を， 2 次史料も含めて，少なくとも現時点では見出していない。このほか，保険業・労 働金庫・信託銀行は，本稿の対象となる業態とは性格が大きく異なり，本稿で一緒に扱うには 適さない。これが検討対象を限定する理由である。

\section{2 金融機関に対する行政指導——経常収支率規制を中心に一}

ここでは上記の本稿第一の課題に関わる問題を検討する。先行研究では(17), 銀行経営に関 わる「諸比率指導」の内容として, 経常収支率規制, 不動産比率規制, 預貸率規制, 自己資本 比率規制，流動性資産比率規制，大口融資規制を挙げている。ここでは，その中でも，特に経 常収支率規制に関わる問題に重点を置いて検討する。

まず，この問題は既に 52 年度史料（79 80頁）で取り上げられた。そこでは総人件費抑制を 中心に収支状況の改善が強く求められた。51年 7 月 5 日付けの蔵銀第3153号には「預金金利と の不均衡」の「是正」のほか，「一般企業」は一層の合理化が実施されているため，「公共性の 高い金融機関として率先して経費節減その他経営合理化につとめること」とある。このほか, 店舗規制も含む（同168～169頁）上記通牒についての解説では，製造業企業の国際競争力強化 の観点から，資金供給機関である銀行には，「率先し」た経費節減を求めた。つまり，日本製 品の輸出競争力強化を目的に，より低い貸出金利でも経営的に成り立つことを可能にするよう

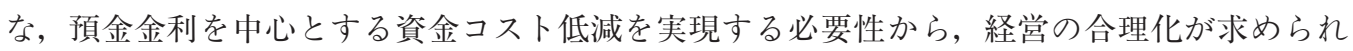
た。翌年度には，相互銀行法制定を受けて，52年 7 月 7 日付けの蔵銀 3190 号などにも見られる ように，無尽も含む相互銀行にも同様に合理化を求めた（53年度史料，254・267～268・272 頁)。

これ以後，52年 9 月 22 日の蔵銀4698号，53年 3 月19日の蔵銀第1084号など，経営合理化を求 める諸通皤が出された。これらは「わが国経済の実情からして経済の正常化を図り，産業の国 際的競争力を培養するために，産業の実質的金利負担を軽減する必要のある」一中略一「(そ のためには一引用者。以下，特記の無い場合は同様。省略）先ず金利引下げを可能ならしめる ような銀行業務の合理化および効率化の方策を取上げ」改善を促す必要性があることや，「こ の際更に（金融機関経営の）合理化，効率化並びに適正化によって経済の正常化と産業の国際 的競争力の培養を図ることが緊要となつた」ことを，その理由に挙げていた（以上，53年度史 料， 158 ・ 162 ・229頁)。周知のように，50年代前半は日本経済が国際経済に本格的に復帰して 間もない時期であった。その状況下で国際競争力を強化する必要性が，経済界を中心に国家的 に強く認識されていた(18)。さらに，企業競争力強化目的の設備資金は銀行借入に強く依存し ており，輸出品のコスト低下実現のためには，資金コストの低下が必要であった。このような 理由で大蔵省は各金融機関に経営合理化=コスト低減を求めた。以上を背景に，53年上期決算

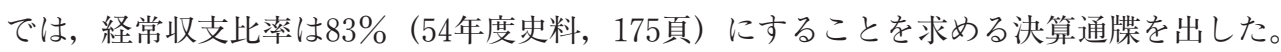
その後も，このような指導は，基準值は異なるものの継続する（普通銀行は78\%，相互銀行 
は $80 \%$ 。 56 年度史料， 112 ・ 179 頁； 57 年度史料 240 頁。数值は 56 年度史料と同様)。その際，問 題になるのは大蔵省の指導が単なる「諸比率」の提示とその達成促進に止まっていたのかとい う点である。この点を検討する上で，興味深い史料が55年度史料に記載されている（以下， 143 146頁)。大蔵省は55年12月22日付けで，55年下期損益予想表徵求の通牒を発し，経費節 減や合理化に関わる所見の提出を各行に求めた。それを踏まえて，56年 3 月 6 日付け通皤「昭 和 30 年度下期決算等当面の銀行経営上留意すべき事項について」では, (1)人件費・物件費の削 減のほか，経費予算制度の強化徹底による経費全般の削減，(2)個別行にとどまらない，各金融 機関の「同業（態）連帯」による合理化，(3)預金商品の複雑化の排除・簡素化，資金吸収別原 価計算の実行と採算のチェックが求められた。これを受けて，各行ともに合理化委員会を新設 し，全国銀行協会連合会でも合理化推進委員会を設置した。さらに業界団体の動きを受けて各 行, 業界団体から大蔵省宛に提出された報告には, 本部機能の強化, 支店長権限の明確化, 支 店の独立採算化, 長期経営計画の導入, 事務処理規定の整備・帳簿書類の書式統一など事務処 理手続きの整備，行員教育の実施など，合計56もの組織的管理体制の問題に関わる改善項目が 示されていた。

地方銀行については，56年 1 月付けで，組織的管理体制の改善状況に関する改善状況の報告 を提出させた。さらに, 地方銀行協会の合理化推進特別委員会にも委員を派遣した（57年度史 料，196 203頁)。このほか，58年 6 月 23 日の全国銀行大会における蔵相演説でも，「経営の合 理化」への「格段の配慮」が求められており, 単なる「経費削減」に止まらない合理化が要求 された (58年度史料, 165頁)。同様に，相互銀行に対しても，普通銀行に順じた指導がされた (同，207 208頁)。さらには，59年 3 月 2 日付けの蔵銀218号「当面の銀行経営上留意すべき 事項について」でも，「諸比率」改善のためにスタッフ機構とコントローラー・システムの確 立を通じた銀行経営の改善が求林た（59年度史料，151・224頁）。これに加えて，60年 4 月 8 日付け通達では，「貿易為替自由化」に対応するため，金利水準引下げも含む日本経済全 体の効率化の一環として，都市銀行と地方銀行に業務計画表と損益予想表を提出させ，コント ローラー制度の確立と長期経営計画の導入を促すとともに ${ }^{(19)}$, 関係する人的資源の育成も求 めた（60年度史料，146 150頁)。

以上，1950年代を通じて，大蔵省は経常収支比率改善のために，単なる数值目標の提示とそ の達成を求めるには止まらない，人的資源の育成も含む金融機関内部の組織的管理体制の改善 を巡る問題にまで踏み込んだ指導を行った。その際，かかる指導は，50年代前半から中葉まで の時期と,「貿易為替自由化」が問題になり始めた 60 年あたり以降の時期とでは歴史的位相は 異なるものの，一貫して金利低下=資金コスト圧縮を通じた，日本経済の国際競争力強化に重 要目標が置かれていた。周知のように，この時期は日本の産業政策全体として輸出競争力の強 化に主眼が置かれていた。ここから，大蔵省銀行局の指導も，このような政策状況を反映した ものと強く推測される。この意味で, 国家的な課題を反映しており, 単なるミクロ次元には止 


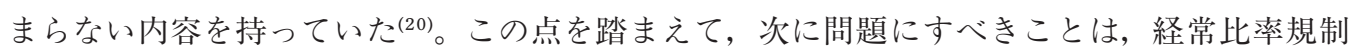
に関しては，大蔵省による「直接介入」が不可能なために，通牒・通達による「諸比率」提示 が実施されたとの先行研究の議論である ${ }^{(21)}$ 。この点の妥当性の如何は, 「個別」金融機関に 「直接」立ち入った金融機関検査の内実, 特に問題認識と指導の内容を吟味することで確認さ れる。以下，50年代における検査体制の変化と検査動向も含めて，この問題を検討する。

\section{3 大蔵省金融検查体制の変容と検査の基本的動向}

戦後復興期には GHQ・日本側ともに金融機関の検査制度改革の必要性を唱え，マニュアル 化・検査官専門化を伴う規模拡充を柱とする，アメリカ・モデルの導入による改革を行っ た ${ }^{(22)}$ 。

まず，これを受けた検査体制の整備状況を確認する。本省の銀行局検査部総員は ${ }^{(23)} ， 51$ 年 度末123名から60年度末 83 名と，50年代を通じて減少傾向にあった。もっとも，検查官（専門 検查官）は42名から61名と増加され，総構成員に占める割合は 3 割台から 7 割台へと上昇す る。これに対して，財務局配置分を見ると総員（兼任検査官十専任検查官）が同様に 82 名から 181名へと一貫して増加した。専任検査官の比率（専任率）も併せて上昇し，33\%から50\%に も達した。このほか, 地域別に見ると, 金融機関数の多い関東（2 割台前半) ・近畿 ( 1 割台 半ば）両財務局，特に前者が突出しており，それ以外は，配置数の少ない北陸を除くと，ほぼ 同様な配置数を示した。その際，戦前との相違点として，専任検査官配置数の増加に見られ る, 専門化の進展には留意すべきである。さらに, 敗戦後における戦時専門官僚支配に対する 批判を踏まえて ${ }^{(24)}$, 金融行政の一環をなす検査に対する一定の説明責任を果たすべく，本稿 で用いる検查報告を『銀行局年報』に掲載した。

次に業態別の検査動向を検討する。金融機関全体に対する検査数の比率（検査率）は，60\% 台から $50 \%$ 程度へと大きく低下する。地方銀行以下の中小企業金融機関全体の比率は低下する が，その值は一貫して 8 割台を維持する。これに対して，都市銀行は51（82\%）・53（100\%） 年度を除き，総じて高くても $40 \%$ 程度と低位であった。全体の検査率低下は 55 年度以降の農協 等への検查対象の拡大が影響している。このことは，検査対象の拡大に応じた体制確保の困難 さを意味する。もつとも，通常検查に加えて，50年代から60年代半ばまでに，52年 8 月，53年 4 月（以上，粉飾預金特別検査），61年 6 ・10月（「都市銀行に対する特別調查」），63年 3 月・ 同年 4 ・5 月（「歩積・両建て預金特別検査」）という特別検査が実行されたほか ${ }^{(25)}, 55$ 年度 からは本省と財務局の検査に際しての相互協力，57年度後半以降は日本銀行考查との「連携強 化」が図られた(26)。

以上，50年代には検査官の専門化の進展とともに，中小企業金融機関を重視した検査が行わ れたのである。 
4 金融機関の組織的経営管理体制に関わる検査官の認識と指導の方向性

（1） 1950年代前半

以下，4 から 7 では，2 で検討した大蔵省の経常収支比率に関わる行政指導方針を受けて実 施された，金融検查における検査官の問題認識や行政指導の方向性の特徵やそれらの妥当性を 検討する。このことを通じて, 検查過程で組織の効率性向上に関わる問題の指摘と改善指導を 実施することで，各金融機関の経常収支比率を是正する方向へ誘導していたことを明確化す る。

既述のように，特に地方銀行以下の階層の業態であるが，1950年代には経営組織の構築と経 営管理が強く問題にされた ${ }^{(27)}$ 。戦後初衫公刊された『年報』である52年度史料（396 4 43 頁）には，銀行一般に共通する課題として，「(1) 一般的に機構によ」る運営への認識の欠落, $\lceil(2)$ 一般的に各部課間の連絡協調」不十分, 「(3) 一般的に審査, 経理, 検査の陣容」の弱体 さが挙げられていた。（1）については，「本部の部課組織と権限は内部規定に」よる「明文化」 が「普通であ」るが，「実際の業務運営」は「特定人物の左右する」状況であることが，(2) については（1）とも相俟って，「各部課間の適当な率制と釣合いが破壞され」，特定部課の発 言力が増大し，十分な運営ができていないことがそれぞれ指摘されていた。（3）については， 経理部門・検查部門の「人員不足」により「十分に機能」していない事例の多さが指摘される 一方で，他方では検査部門は「構成員の質的貧困，急慢等に（問題が）あることが多い」との 指摘が出された。組織内の各部・各課間の調整も含めて, 組織的な管理体制の構築の不十分さ が認識された。1950年代は独立の部（課）としての企画部（課）・検査部（課）設置が始まり， 漸く組織構築上，これらの諸部門の重要性が認識され始めたところであった (表 2 )。特に企 画部門に関しては, 個別事例にすぎないが, 設置直後にはその重要性が十分に認識されず，各 部・各課の調整に苦労したとの証言もある(28)。検査官の認識は，このような経営実態に基づ くと推定される。このほか, 都市銀行についてのみ管理部門の肥大化による不当な「管理費用 の増嵩」が指摘された。都市銀行全体の経常収支比率を見ると，50年上期の $79.8 \%$ から 51 年上 期には $80.8 \%$ に上昇していた（54年度史料 224 頁）。検査官の指摘の妥当性が，一定程度，確認 される。

ほぼ同様な指摘は，相互銀行も見出せる ${ }^{(29)}$ 。まず，相互銀行・無尽については，「(1) 役職 員の素質に関する問題 / (2) 経営方法の問題」に大別される。前者については「人的素質が劣 弱」であることが指摘された。具体的には，「役員中」の事業の「私物視」，および「公私を混 こうし, 情実的な融資及び人事」の実施, 職員の事務処理能力の低位と研究心の乏しさや, こ れに伴う帳簿記帳整理の杜撰化, 多数の経理ミスの発生が指摘された。このほか, 外務職員の 管理の不適切さも強く指摘された ${ }^{(30)}$ 。翌年になるとさらなる問題点として, 企画指導・内部 監査部門の弱体さが指摘されていた。（2）については，(1)融資時の勘や「外面的な一部の評判 等」への依存傾向の強さ，(2)「計数観念にそしく損益収支，原価計算等の正確な把握が」され 
ていないこと, (3)「帳簿書式が極めて複雑多岐」であることが指摘された。行員の質的貧困に 加えて, 組織運営の前提となる帳簿類, 規定類の整備という, 組織管理の初歩すらできていな いことが問題視された(31)。

大蔵検査官の指導の効果は，地方銀行に関しては，比較的早期に顕れたと認識された。54年 度史料（453頁）には全般的な本部機構整備の進捗，内規・事務処理規定の制定努力など「業 務運営体制の一新をみ」たとある。もっとも, 問題点として, 効果があった事例数の少なさを 論じた。その上で, それらの原因として首脳陣の機構による運営の未実施, 経営規模を考慮し ない機構整備と人員配置, 業務分量・事務分掌の不明確さ, 各部課の連絡調整の不十分さを挙 げた。さらに人的資源と組織構築のミスマッチを重要視していた。度重なる検査経験を通じ て, 検査官により認識された問題の焦点は, 事務処理規定の整備といった基本事項から組織間 の業務分担関係や人員配置・人的資源の育成など, 組織運営の効率化と円滑化に関わる問題へ と変化した。後述のように，このような方向性は50年代後半にも継承された。なお，行内「検 查陣容の充実による各店貸出の統制, 内容の把握と検查励行による事務的改善, 不祥事件の防 止等」は「比較的短期に効果が挙つた」とされ，一定の改善を認めていた。

\section{（2） 1950年代後半}

50 年代後半になると, 機構整備の進展度の業態間格差が明確化する。まず，地方銀行につい て検討する。55年度史料（282頁）でも機構整備の進展度が業績に反映してきたことが，56年 度史料（354 356頁）では前年度に指摘した資産内容，業容進展度合いと機構整備との密接な 関係は金融緩慢に状況が「一転」しても「引続き」変化がないことがそれぞれ指摘された。57 年度史料（405頁）でも組織的な管理・運営体制強化の進展と，これを反映した本部職員の構 成員比率の上昇（管理部門の充実）も認識された。

もっとも, 同時に，特に「支店長や次席の人材払底」という，人材養成，人事管理面で組織 化が困難に逢着しているという限界も指摘された。「この階層に人が揃っている」のは「本年 度被検查銀行の中で $3 \sim 4$ 行, 全国地方銀行をみても $5 \sim 6$ 行」として, 検査官は問題視して いた。さらに，58年度史料（398～399頁）では11「頭取の独断独裁で行われ，組織が無視さ れ」ている銀行や，(2)役員の「融和の欠如」した銀行の存在 ${ }^{(32)}$, (3)本部機構の弱体さ（特に, 「総合企画性と組織の有機的連携」の欠如； 59年度史料，425頁), (4)権限・責任の範囲の不明 確さ，(5)権限の幹部への集中による部長・次長・課長などの中間管理職の責任感の希薄化も指 摘された。以上の問題や, 後述する経理面等で問題を孕みつつも, 地方銀行に関しては, 大蔵 省の検查と指導により, 経営組織の構築とこれに基づく管理・運営面では一定の効果が現れて いたと認識された。

その後, 度重なる検査を通じて得た，このような問題改善認識を踏まえて，問題認識の焦点 は再び変化する。つまり，この点は財務面を検討する際に詳論するが，この基盤の上に，50年 
代末になると，総合予算制度に見られる経営の計画化の進展が指摘された。ただし，この時期 には，総合予算制度の導入ははじまったばかりであった (表 2 原史料。前述)。このことを検 査官は問題視した。この現象は総合企画部設置を通じた企画機能の強化を伴ったが，60年代初 頭において，検查官側は「連絡調整」機関に過ぎないとのマイナス面の指摘をしつつも，「長 期経営計画の策定，管理」や「営業店個別指導につながる」として歓迎した ${ }^{(33)}$ 。

しかし，それ以外の業態では，この問題の大きな改善は認識されなかった。この点を相互銀 行から確認する。56年度史料（376頁）には「本部機構／本部機構の整備」は，(1)「一般に」 整備が進んだが，経営規模に対して過大なものがあり，これに伴い人員不足や「質的貧困」で 機能していないこと，(2)機構が形式的に止まっていること，(3)「外務員による掛金費消」「内 勤職員による行金横領費消」など不祥事件の増加，(4)重大欠陥としての「外務員監督の不徽 底，人事交流の停滞等人事管理の欠陥」「相互牽制」の未確立，(5)「内部監査の不徽底」が指 摘されていた。確かに実態としては機構そのものの整備は進展していた（前掲表 2 )。しかし ながら，50年代後半になっても，主に人的資源の問題を背景として，その改善（「近代官僚制」 化，形式合理化）は殆ど未進展であると認識されていた。

5 財務管理体制に関わる問題認識

（1）普通銀行一地方銀行を中心に

ここでは，地方銀行を中心に財務管理体制に関わる検査官の認識を検討する。52年度史料 （403頁）では普通銀行全般について「一般的に審查，経理，検査の陣容が弱体」なことが指摘 された。この内，経理については損益等の分析と検討が不十分な銀行が「地方銀行中に散見さ れ」，その原因が行員の「質的貧困，急慢等にあることが多い」との認識がある。計数分析が 欠如した経営が地方銀行に見られ，その要因が行員の「質的貧困，总慢等」属人的資質に求め られていた。さらに，翌53年度史料（514頁）でも，そのため資金計画の漫然とした前期実績 の踏襲を背景とする計画と実績の乘離や，債務者に引きずられ，資金手当に忙殺されるなどの 「不安定な運営を」継続しており，その結果，貨出債権の健全性維持にまで影響していたと認 識された。人的資源のあり方が問題の焦点と認識されていた。

このような問題認識のあり方は，50年代中葉以降になると変化する。この時期，地方銀行で は組織的な経営管理体制の整備が進展したと認識された（前述）。しかし，この状況の下で 「経理部を素通りして経営方針が営業部門に連絡し, 経理部が計数の集計とか, 業績の結果を 数字の上に現わす機関視」される傾向があり，「数理にたつ企画性にまだまだ経営者がうとい」 との問題が指摘された（55年度史料 283 頁）。さらに，56年度史料（359頁）では地方銀行への 原価管理に基づくコスト低減要求には無理があることが指摘されており, 財務管理に関する専 門知識に基づく，経営の未進展も限界として認識された。しかし，57年度史料（405頁）では， 事務合理化状況が検討され, 財務管理に関しては内部機構の再編成, 行員教育の充実, 総合予 
算制度の導入や改善の進展が指摘された。もっとも，58年度史料（397頁）では，特に内部機 構再編成との関連で, 具体的に組織内部での経理部の立場の弱さ, 営業店に引きずられる傾向 の強さという，営業部門に対する財務部門の統轄力の弱さが指摘された。

さらに，上記の問題改善についての認識を踏まえて，翌59年度史料（425頁）では導入が進 んでいた総合予算制度について，これにより「本部の連絡調整，支店の指導統制に顕著な進歩 を見せているものがある」ことを評価する認識を示した。もつとも，「単純に収支予想から」 逆算されており,「計数的根拠に合理的信憑性」が欠落しているため, 経営管理統制の指標と して効果がそしい事例が多く，なおかつ「編成過程」で「単に前年度実績または預金増加のみ を基準として各店毎に個別的検討が」なく，予算超過を「安易に容認しているため」，予算が 単なる予算表化している事例が見られることが指摘された。検查官側は，計画を実行する規律 面で，特に問題を認識しており，この意味で，特に財務面での経営の計画性に問題を認識して いた。

\section{（2） 相互銀行}

これが相互銀行になると，より厳しい指摘がされた。52年度史料（409～413頁）では，相互 銀行に関しては(1)「計数観念に乏しく損益収支，原価計算等の正確な把握が」されておらず， 「経費の繰り延べ, 給付補塡準備金及び未払利息の不適正計上等のため, 損益の実態が歪曲さ れ，経費率及び収益利迴が不明確」なこと，(2)「帳簿組織が極めて複雑多岐」「旧態のまま」 のため「事務上徒らな煩雑と誤謬を招来する」ことが指摘された。この状況は，52年度におい て預金が $80.1 \%$ ・貸出が $76.0 \%$ も増加し（掛け金は $40.5 \%$, 給付金は $27.2 \% ; 52$ 年度史料 524 529頁)，「相互銀行の普通銀行的な性格を急速にクローズ・アップ」しているなど経営規 模と内容の両面での大きな变化にもかかわらず，「計数的基礎の上に立つた経営」の実施や 「帳簿組織の簡素化, 合理化, 能率化」の遅延についての指摘にもあるように, 大きな改善は 見られないと認識されていた。

この状況は，検査官の認識によれば，50年代中葉以降，改善を示したようである。55年度史 料（306頁）によれば「未使用重要用紙類の受払保管，予備株券の保管等」が乱雑な銀行が見 受けられるとしつつも,「記帳記録, 手形証書の保管整理等の事務取扱」の不備の減少が認め られた。その上で，掛金契約関係諸帳簿について「複雑な記帳様式が事務能率を阻害している ものも見受けられる」との指摘がされた。ただし，57年度史料（422頁）では検査対象の 3 分 の 1 の相互銀行で, 機構整備上の問題の一環として,「経理部門が後退し業務部門のみ前進し 運営は跛行状態」であることが指摘されている。59年度史料（432頁）にも「経理部で融資規 制方針を打出しているが審査部が強調しないため無意味に終わっているもの」もあるとの，ほ ぼ同様の指摘がある。以上，審査部に見られる業務部門が貸出・預金などの経営規模の拡大を 優先して，財務部門の統括が有効性を発揮していないことを，検査官たちは問題視していた。 
もつとも，相互銀行も地方銀行に遅延する形で組織整備が進展していた。その過程で業務部 門の改善・充実が専ら取り上げられ, 組織規模拡大に見合う形での財務部門の充実が疎かにさ れていたと認識されていた。経営全体に関しても，60年度史料（454頁）で「天降り的な割当 資金量の督励以外には，営業店指導のみるべき方策がなく，経営に総合的な企画性，計画性が みられず」，少なから娘行が「営業店の実体把握にかける」とされていた。相互銀行に関し ては財務管理に基づく組織的かつ形式合理的な経営管理態勢の構築は, この時点に至っても未 構築であると認識されていた。

\section{(3) 小括}

財務管理の問題は，特に地方銀行以下の階層で問題視されていたが，その位相は業態により 異なる。つまり，組織的な経営管理体制の構築が進展していた地方銀行は，組織内部における 財務管理部門の機能と役割のあり方が問題視された。これに対して，地方銀行に遅延して組織 整備が進められた相互銀行では，財務部門を中核とする企画性・計画性に基づく経営の欠落が 問題視された。なお，財務管理部門に関する問題は都市銀行では指摘を受けていない。

6 貸出業務に関わる認識——審査・監督を中心に——(34)

（1）普通銀行一地方銀行を中心に

ここでは地方銀行を中心とする普通銀行の貸出手続の問題を検討する。52年度史料（404頁） では「信用調査については，数年前に比較すれば各行とも可成りの改善が認められる」とされ た。その上で，具体的内容として(1)禀議書も含めて科学的信用調査の様式を整えた点，(2)取引 先財務諸表等の調査資料の店舗への備付け，(3)ごく一部の銀行ながら，信用分析基準を設定し た上で，等級別に貸出条件に制約を加えていることが挙げられていた。しかしながら，「依然 として対人信用に依存する貸出が跡を絶たず，『事業』に対する認識に欠け徒らに『勘』に依 存して信用調査軽視の傾向は払拭されていない」ことも挙げられていた。さらには，情実的貸 出，役職員関係の貸出金も「多くの銀行に認听」とされていた。つまり，これらの面も 含めて事業分析に基づく事前審査・リスク管理は徹底しておらず，属人的要素に依存した貸出 審査の実施が広汎であったと認識されていた。この意味で，科学的かつ形式合理的な審查体制 の構築は不十分であると認識されていた。

以上の状況は，地方銀行は53年度（514頁)，都市銀行は54年度（439〜440頁）も同様であ る。ただし，地方銀行については54年度史料（454頁）中で，少数ながらも協調融資等の域外 貸出が問題視された。さらに55年度史料（288～289頁）では，一方では金融引締による貸出先 選別，債権保全工作の強化と内部検査による保全上の欠陥についての指導推進の必要性が指摘 された。もっとも，他方では「新規既存を問わず担保徴求が進み」一中略一「これが書換継続 を甘くさせ」たとの指摘が付け加えられた。この意味で，債権保全対策の改善は不十分との認 


\section{経営史学 第 43 巻第 4 号}

識が窅える。

これが57年度史料（414頁）になると，本部機構整備，ひいては審査体制の整備状況の如何 で，経営内容に格差が発生していることが指摘された。このほか，翌58年度史料（400頁）に は, 「貸出金の調査, 番查振りは, 一般的に, 依然として科学的でなく, 担保, 従来の預貸金 取引状況世間的風評などにたよるのみで，実体的ではない」とあり，リスク管理体制の強化が 見られた地方銀行は比率的に少なかったという。 59 年度史料 (426〜 427頁)，60年度史料（450 頁）でもほぼ同様の指摘がされた。審査体制の整備・科学化という点で未だ問題が残ると認識 されていた。

以上，特に地方銀行について，組織的な経営管理体制構築の進展度の如何により，各行間で の形式合理的かつ科学的な貸出リスク管理体勢の構築の格差発生が指摘された。このほか 50 年 代中葉以降の担保，特に不動産担保徵収が，審査・監督体制の弛緩を招いたとも認識された。 高橋俊英大蔵省検查部長の 61 年の全国地方銀行協会における講演でも，地方銀行の融資姿勢と して, 稟議書類の複雑化・文書の圥長さや審査に重点を置かない担保主義が指摘されてい た ${ }^{(35)}$ 。60年代初頭に至っても，この状況は未改善と認識されていた。なお，都市銀行につい ては50年代中葉以降，この指摘は見られない。

\section{(2) 相互銀行}

次に相互銀行を検討する。 52 年度史料（410頁）では融資時の組織的調査の未実施と「勘」 や世評などへの依存傾向の強さが問題視された。さらには, 資産内容不良の主因として, 役員 の素質の劣弱さが指摘されており, 資産の健全性維持に対する経営者の無理解が, 内容不良化 の重要要因であるとの認識も確認できる。後者も「不良資産発生の原因は事前調査の粗漏, 事 後管理の不徹底，情実介在の 3 点に要約できる」（412頁）とされ，特に事前調查は信用分析が 不十分で「世評，勘による貸出許与が多い」と指摘された。ほぼ同様な事柄は，53〜 56年度史 料でも指摘された ${ }^{(36)}$ 。しかも，55年度以降では相互銀行の貸出債権の大口化，56年度史料で は不動産担保への依存による審査・監督（貸出リスク管理）の弛緩も指摘された。特に，54年 度史料（465頁）では，(1)貸付金の管理不十分，(2)延滞口への漫然とした貸増，(3)本部による 支店貸出実態の未把握と無稟議, 条例違反の貸出の多さ, (4)書換, 貸増の放任を指摘した上 で，その背景として「給付金と貸付金の根本的相違」への不認識が論じられた。貸出審査・管 理体制の非科学性・無規律性の貸出債権管理への悪影響が問題視された。

しかし，57年度史料（419頁）になると，相互銀行は上記問題の残存が指摘されつつも，「審 査機構の拡充, 管理部門の整備の外, さらには収益力増加に伴う償却の増加等」も指摘され, 状況の改善が認識された。ただし，大口貸出債権については，「堅実な融資方針の樹立或は融 資の基本的態度（良質契約の厳選，債務者の厳選——史料原文。引用者）等については，さら に一層の改善を要するもの」があるとの指摘もあり，この面では問題改善の弱さも認識されて 
いた。これが58年度史料（403頁）では「検査相互銀行 38 行のうち」, 資産分類率改善が 21 行, 同率が 2 行, 悪化が15行とされ，次年度以降も貸出債権の審査・管理体制構築の奏効が認識さ れた。ただし，59年度史料（430４31頁）では，検査対象39行中，良化したものが23行である ことが指摘された。その上で資産内容が悪化ないし横ばいであった 16 行について，事後管理も 含む「大口融資を扱う審査能力」の欠如にもかかわらず，大口貸出を増加したことによる内容 悪化が指摘された。さらに，60年度史料（453頁）では, 検査対象40行中の33行について，資 産内容が好転したものが 24 行, 上昇率 $1 \%$ を超えるものが 2 行に過ぎないことが示された。そ の原因として業容拡大重視による融資の放漫化, 内部管理体制充実の未進展が指摘された。高 度成長下において経営規模が拡大する中で，貸出債権の健全性維持に関する内部体制の充実が 疎かにされた事例が多数指摘された。このことが相互銀行の経営管理体制の充実への動きを制 限したとの認識が窅える。

以上，50年代初頭には，検査官たちから相互銀行は貸出債権の審査・監督体制の非科学性が 指摘されていた。しかし，50年代中葉以降，相互銀行の体制整備は進展したと認識された。こ のほか，50年代末葉以降の経営規模拡大が相互銀行の管理体制充実への動きを制約したと認識 された。検査官はこの問題の改善を重視したのである。

\section{7 受検銀行側から見た金融検査官の問題認識}

ここでは厳しい史料制約があるため，地方銀行を中心にしつつも，2次史料ではあるが，副 次的に相互銀行側も取り上げて，6まで見てきた大蔵省金融検査官の問題認識を，どのように 受検銀行側が受け止めていたのかを考察する。同時に, ここでの考察は, 『年報』における記 述と被検査銀行側の検査への対応や経営の実態との対比を通じて, 『年報』の記述の妥当性を 確認することをも目的とする。

\section{(1) 『銀行の検查方式』(37)に見られる地方銀行業界の認識}

最初に1954年に全国地方銀行協会が作成した内部検査の手引書である『銀行の検査方式』 （以下，本書と略記）を取り上げて，地方銀行側が大蔵省の問題認識に基づく指導をどのよう に受け止めたのか, という点を考察する。本書の作成にあたり, 大蔵省検査部から検査部長と 金融検查官の 2 名が参加し, 協会側を指導していた。協会側も, 各地の地方銀行の検查を通じ て, 新検査方式策定の必要性を痛感し，ここ二年程「各種資料の蒐集・研究を」してきた「大 蔵省検查部御当局の示唆と資料の御提供に基づく」,「大蔵省当局における長い準備段階がこの 結果を生んだ基礎である」としていた。つまり，本書の内容には大蔵省金融検查官の問題認識 が強く反映しており，かつ，業界側もこれを妥当なものとして受容していた。

この点を踏まえて，紙幅の関係上，主なもののみにはなるが，本書での具体的な指摘内容を 検討する。まず，経営組織面では(1)「分課組織乃至事務分担の適否」，(2)「牽制組織，二重管 
理制の実施状況の適否」, (3)「人員数の適否」, (4)「次長, 副長等補佐者設置の要否」が問題に されている。(1)については,「人のために特に設けられた課や係はないか」，(3)については部課 などの「人員数はそれぞれの責任者が監督し牽制し得る範囲を超えていないか」，(4)について は「次長，副長等補佐者は監督の範囲及び担当事務の性質に照らして必要か」とある。さら に,「帳簿組織または伝票書類の様式の適否」という項目では, 「取引の種類, 業務量から見て 現在の帳簿組織のうち事務処理上支障を生ずる点はないか，また改善した方が事務能率の向上 に資すると思われる点はないか」とある。これらの指摘は, 経営組織の効率性を問題視した, 前述の大蔵省側の問題認識と共通する。このほか, 信用調査については「紹介貸出或は有名人 に対する貸出金で信用状態, 返済方法等に関する調査不十分なもの」への着目の必要性が，債 務者や保証人については「業態推移を常に把握しているか，これがために定期的にまた必要に 応じて随時, 財務諸表その他必要書類を徵求して常に分析検討しているか」ということがそれ ぞれ論じられた。これらの諸点は, 地方有力者への貸出の際の属人的資質に依拠した非科学的 審査の実施に対する大蔵省側の批判（前述）とも照合する。最後に，「内部牽制組織実施上の 留意事項」を検討する。そこでは，まず，「内部牽制組織」の定義として，各係員が担当する 事務が，他の係員の事務により「組織的かつ自動的に検証される」事務管理組織とされてい る。続いて, この定義に基づき,「経理手続ならびに事務取扱について全店に共通の準拠すべ き一般的標準を設定し，この標準に基き運営する」とある。さらには，各行員の業務範囲と責 任の明確化も指摘されていた。これらの諸点は, 特定人物が組織行動を左右することや, 行員 の個人的経験に基づく事務処理，ならびに権限の範囲と責任の所在の不明確さを批判する，前 述の大蔵省側の問題認識とも符合する。これらに加えて, 本書では, 現金などの「保管係を定 め，保管係と役席者との二重管理にするのが最も適切である」ことも論じている。

以上，本書が提起した検査方式は，地方銀行など各金融機関の実地検査を通じた大蔵省金融 検査官の問題認識を強く反映していた。さらに，業界団体側もその妥当性を認めていた。それ では，このような本書の内容を現場で実務を担当していた地方銀行の行員側はどのように受け 止めたのであろうか。この点を高山信介「『銀行の検査方式』私感若干」(38)を用いて検討する。 本論考は本書に対して地方銀行の実務者の立場から論評を加えたものである。まず，全般的な 反応であるが，「思わず『これなる哉』と絶賛するとともに，銀行の業務運営面に，また事務 方式の面に教えられる点, 反省させられる点が多々あった」とある。つまり, 基本的に本書の 指摘を妥当なものと受け止めていた。次に本書の内容についての具体的論評である。まず, 「第五の『内部牽制組織の要領』の如きは, 地方銀行として最も重要な課題であり, 実施され なければならない事項であろう／殊に二重管理の不充分は痛切に感づる処で, 行員不正の温床 となうてい方感さ充方」とある。さらに, 本書での「諸規定の制定或いは整備, 経営政策の 具体的実施のための通達類の周知, 予算による標準の設定, 権限と責任の明確化, 下部組織へ の権限委譲等，各種の条件が満たされなければならない」との指摘についても，「事実このよ 
うに，先ず諸規定の制定乃至は整備が（経営管理体制の構築のための）前提的な条件となる」 としている。これら諸事項は, 上述のとおり，大蔵省金融検査で，度々，指摘されていた。こ れらのことを筆者は地方銀行の実務者として，傍点部分に見られるように，人的資源の問題も 含めてほぼ全面的に肯定している。

以上から，少なくとも，金融検査を通じた大蔵省側の経営問題認識の核心部分に関しては， 業界としてはもちろんのこと，地方銀行の行員側もこれを是認していたと言えよう。

（2）地方銀行のケース (1)：1950年前後における埼玉銀行の事例

（2）と（3）では，1950年前後における埼玉銀行と地方銀行 A を事例に，1950年代における 大蔵省金融検査と組織的管理体制の構築との関係を検討する。事例数は僅か地方銀行 2 行に限 定される。しかし，戦前期でさえ受検銀行側の対応が分かる事例が数例に限定されることを考 虑した時(39)，現状では止むを得ない制約であろう。

まず，埼玉銀行である。同行は判明する限り1949年下半期と51年 1 月から 2 月に大蔵省検査 を受けている。まず，51年の検査講評では「重役並に行員諸君が心血を注ぎ和褁奮斗せる結果 (中略)『総合的に見て実によく改善されている」」との評価を得たとして，51年 1 月27日の支 店長会議ではこのような結果を喜んでいた ${ }^{(40)}$ 。それでは，49年下半期の検査ではどのような 指摘を受けたのであろうか。この点を明示する史料は存在しない。ただし，上記の支店長会議 ではこの間の業績低迷の理由として, 武州・八十五両行出身の重役間対立と不祥事件の発生 や，これらに基づく行員の「土気沈滞」と不正行為，ならびに不良債権の発生が挙げられてい た。さらに，この間，「融資と監理両部の併合」に見られる貸出リスク管理体制の強化，「支店 長に対する一定貸出権限の付与」, 取引先などからの「饗応」を受けることの禁止, 役員数の 半減に見られる重役組織の簡素化，行員採用・行員養成体制の整備を通じた人的資源の質の向 上といった改革が図られていた。これらに加えて，平沼頭取（当時）は，上記の諸問題を原因 として，この時期の「行内の空気はただれており」，「検査の都度，検査官にいじめられた」と 回顧している(41)。

同行の内情がこのようなものであり，上記諸点についての改善が四られた上で大蔵検査官の 講評でも改善努力が評価されていることや，上記の支店長会議で挙げられた改善が図られた諸 問題と大蔵検査官による講評結果に対する喜び様を踏まえた場合，49年下半期の検査では上記 の諸点が，検査官により問題点として指摘を受け，なおかつ埼玉銀行側もその指摘を妥当なも のとして受け入れた上で改善に取り組んだと判断される。なお，指摘を受けたと推定される諸 点は，50年代前半に関するリスク管理体制の甘さ，行員の質的貧困，特定人物による銀行経営 の支配，50年代中葉に向けての地方銀行の経営管理体制の改善への動きといった，前述した大 蔵検査官の指摘とほぼ符号する(42)。 
（3）地方銀行のケース(2)：Aの事例

次に，地方銀行 A を取り上げて，1950年から60年までの検査と組織管理体制の整備との関 係を検討する ${ }^{(43)}$ 。同行は60年末地方銀行平均預金量450億円を大きく下回る，比較的小規模な 銀行であった。この間，現時点で確認可能な残存史料によれば，同行は50年，52年，54年，56 年，58年，60年に各 1 回，計 6 回の検査を受けている。このほかにも検查を受けた可能性は否 定できないが，とりあえず，史料の制約もあることから，これらの検査史料を用いて検討す る。

最初の検查では，戦時下における銀行合同過程以来，未実現のままでいた全店舗の統一的事 務規定の整備, 信用調査を中心とする貸出審査の科学化, 検查規定の制定を含む内部検査の充 実の必要性のほか，保護預かり関係書類の整理保管体制の整備の必要性が指摘された。これに 対して, 内部検查に関する指摘についての答申は史料中に見られなかったものの, それ以外に ついて A はこれらの指摘の妥当性を認めた上で，その改善に取り組むという答申を提出した。 2 回目の検查では本部機構の整備と内規・事務取扱規程の整備の必要性が指摘された。これに ついても指摘の妥当性を認めて，これらの整備に関する委員会の設置や行員・幹部の育成会・ 事務研究会を組織し，その改善に取り組むことを答申した。3 回目の検査では事務取扱規程の 制定の遅延が指摘された。これについても, 指摘それ自体の妥当性を認めた上で, 一部は完成 しており，逐次，営業店に示達していることや，近く全編完成見込みであることを答申した。

4 回目の検査では，予算制度の活用を通じた合理化の必要性が指摘された。その上で，本部 機構と事務組織については改善が見られるものの, 十分に活用されていないので, さらなる改 善の必要性が指摘された。このほか, 内部検査体制の充実を含む内部監査体制の強化, 営業店 長への貸出専決権限の付与を通じた貸出禀議制度・審査体制の強化, 貸出先の経営分析の強化 といった貸出金審査体制・貸出債権管理の強化の必要性も指摘された。これらについての答申 は現時点では確認されていない。しかし，第 4 回検査に関する史料薄冊に合綴されている文書 中には，このような指摘に対して特に異論を唱えた形跡は見らない。ここから検査官の指摘を 受容したと推定される。5 回目の検査では, 予算統制の厳格化を含む長期経営計画の導入の必 要性と内部事務の合理化, 市場調查の導入, 規模拡大に対応した業務部組織の整備, および各 課の有機的運用を図る必要性が指摘された。これについても, その指摘の妥当性を認めた上 で，役員室直轄の総合企画部の設置を通じた各部の管理と調整による経営の計画化と予算統制 の厳格化, 業務・経理・融資の 3 課からなる業務機構を拡充した上で, 予算統制面から組織全 体を総合的に管理することを柱とする改善を考えている旨の答申が出された。最後に 6 回目の 検査の際には, 組織を構成する各部, 各課の統制強化を通じた本部機能の発揮と営業店統制の 強化や，これらを通じた経営合理化の必要性が指摘された。これらの指摘に対しては，貸出禀 議については権限の下部組織への委譲とこれに対応した諸規定, 諸手段を講じることにより, 行員の士気を向上させるとともに，業務の効率化を図ることが答申された。このほか，本部機 
構の強化に関わって, 常務会の確立ならびにこれに直属する総務部設置を通じて, 経済の長期 的動向を踏まえた長期経営計画の策定，総合予算制度の導入を通じた経営近代化を図ることを 目的に, 経営合理化・事務改善に関わる委員会の設置が答申された。ただし，当時の同行関係 者への聞き取り調査によれば，コントローラー制度の導入にあたり，各部・各課の関係者たち の理解が不足しており, 組織間調整は難航したという。ここから, 経営のトップレベルでは大 蔵省に対しては行政指導へ積極的に対応する姿勢を示したものの, 実際に現場レベルでの実践 となると相当の困難があったことが確認される。

以上，50年代後半になると，検査官の指摘の中心は，それまでの書類管理や事務処理規定の 整備, 貸出審査体制・管理体制の科学化を中心とするものから, 予算・財務管理を含む経営の 計画化とこれに伴う本部機構の強化，ならびに上部組織への権限集中の問題とその是正に関す るものに変化する。これらの指摘もまた，前述した検査官の問題認識とほぼ符号する。受検銀 行である $\mathrm{A} も$, 積極的であるか否かはともかく, 一応は, その指摘を基本的に妥当であると 認めた上で, 行員の育成も含む対応に取り組み, しかも, 改善すべき点についての指摘を受け ながら，検査官の指摘を踏まえて経営管理体制の改善を進めたと検査官に認識されたことが確 認される。なお，人材育成体制の整備に伴い，人的資源の質に関する指摘はなくなる。ここか ら, 前述のような検查官が指摘した人的資源の質の問題は, 実際には行員市属之的能力方市

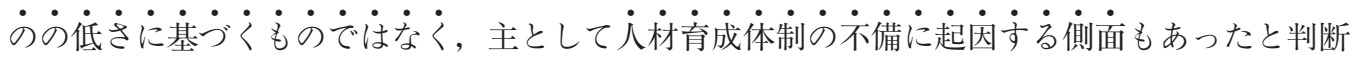
される。Aの事例から判断する限り, 上述のような検査官の指摘は, 少なくとも, 受検銀行 側には妥当性のあるものとして受け入れており，その上で組織的管理体制の整備が図られたと 言える。このような大蔵省の指導を踏まえた改善への取組みによって, Aの経常収支率は50 年 3 月期の $93 \%$ から 55 年 3 月期には $88 \% ， 60$ 年 3 月期には $89 \%$ と，理由は不明であるが 50 年代 後半になると停滞するものの, 基本的には50年代を通じて改善の方向性を示した。このほか, $\mathrm{A}$ の経営実態からして,『新しい銀行検査法』の記載事項は, 金融検査官が指摘したことでも あり，なおかつ地方銀行経営の実態に基づいていたことも確認される。

\section{（4）相互銀行側の認識}

ここでは，傍証ではあるが，史料の制約もあり，各行の『銀行史』の記述などから相互銀行 の検査での指摘の受け止方を確認する。まず，相互銀行以下層も，業界全体として，経営管 理講習会や実務講習など, 経営近代化・業務の「科学化」とその基盤となる人材育成, 特に 「勘と経験に頼り勝ちな経営」からの脱却目的の研修会を実施した（前掲表 1 )。これらの諸点 は大蔵省金融検査官が指摘した問題でもあった。ここから業態全体としてこれらの諸問題の解 決の必要性を認識していたと言える。

以上を踏まえて，検査官の指導に対する個別行の認識を幾つかの事例から検討する。弘前相 互銀行は ${ }^{(4)} ，$ 具体的内容は不明であるが，55年 5 月実施の大蔵省検査で内部管理体制整備の 
必要性の指摘を受けた。これを「指針に」56年 5 月には企画室と審査第一課・二課をもつ審査 部を新たに設置した上で, 経営帳簿類の整備, 原価計算制度, 経営方針を決定する経営会を設 置・導入する組織改革を実施した。第一に，この内容から大蔵省の指摘が帳簿類の整備や組織 的な貸出審査体制の整備という基本的事項も含む内部管理体制の充実であったことが強く推定 される。第二に，大蔵省からの指導を「指針」にしたことに見られるように，曲がりなりにも 大蔵省側の指摘を妥当なものとして受容した上で, 組織改革に臨んだことが分かる。

山陽相互銀行では(45)，具体的内容は不明であるが，53年 3 月から56年 6 月まで 6 次にわた る事務分掌規定改正を中心とする組織的管理体制の強化を目標とする本部機構改革を実施し た。その際に同行側は大蔵省の指導の重要性を認めていた。ここから大蔵省の指導内容の眼目 は本部機構の機能強化と整備であったことが推定される。さらに，山口相互銀行は53年 6 月の 大蔵検查で掛金の延滞のほか ${ }^{(46)}$, 内部機構整備の必要性と職員の能力向上など訓練の問題に ついての指摘を受けた。同行はその指摘の妥当性を認めて, 本部機能の強化, 内部監查制度の 確立，掛金延滞の整理を図った。ここから監査に見られる内部チェック体制の強化と不良債権 処理が指導の眼目であったことや, 大蔵省の指導が妥当なものとして受容されていたことが確 認される。松江相互銀行も ${ }^{(47)}$ ，内部管理体制の整備期である50年代前半から中葉期である5 3 年 5 月と 55 年 8 月に大蔵検查を受検した。具体的な指導内容は不明であるが, 特に後者は, こ の間の体制整備の「試金石」とされていた。ここから，同行は検査を通じた指摘を受容した上 で，組織的管理体制を整備したことが確認される。このほか，新潟相互銀行(48)も61年11月の 大蔵検查で59年下期から 64 年上期までの 5 力年計画の提出を求められた。これ契機に 60 年代に 入って漸く経営計画化に着手していた。ここにも経営の計画化促進に対する大蔵省の指導の影 響が確認される。

以上の諸事例で取り組まれたことの多くは，大蔵省金融検査官が問題にした事柄であった (前述)。さらに, 組織的管理体制の改善にあたり, 積極的であるか否かはともかく, 一応は, 各行とも検査官の指摘を受容するか, それを念頭に置いていた。さらに，これら相互銀行の諸 事例と前述した埼玉銀行や地方銀行 A と比較した時, 相互銀行の管理体制整備の遅れが確認 できる。この点は前述した金融検查官の認識の妥当性を一定程度裏付ける。なお，このように 地方銀行と相互銀行との間で組織的管理体制の整備・構築の進展度の相違が生じた理由は, 現 時点では全く不明である。しかしながら, 相互銀行の前身である無尽とは異なり, 戦前以来, 地方銀行は組織的管理体制の整備に関わる検查と指導を受けており, 組織的管理体制の整備に ついては相対的にはあるがそれなりの歴史的経験を積んでいた ${ }^{(49)}$ このことが, 両者の相違 を生んだ背景であると推測される。

（5）経常収支率改善に対する指導の効果，『年報』の記述の妥当性

これらの諸事例から, 史料の制約上, 地方銀行における組織的管理体制構築の進展度の規模 
別格差など，その妥当性が確認できなかった部分があるものの，大蔵省の認識と指導の方向性 は概ね適切であるとして受け入れられるか（地方銀行），ないしは適切さの如何は確認できな いにしても，各金融機関はこれを肯定的に受容する形で組織体制の整備・改善に取り組んでい た（相互銀行）と言える。このほか, 地方銀行と相互銀行の間に組織的管理体制の構築度の差 異があったことも一応確認されよう。これらを踏まえて，その改善を直接の指導目標にした経 常収支率の改善状況を確認する（以下，各年度史料による）。50年上期（都市銀行・地方銀行 のみ), 55 年上期， 60 年上期の業態別の数值を示すと，都市銀行は $79.8 \% \rightarrow 77.2 \% \rightarrow 83.4 \%$, 地方銀行は $79.1 \% \rightarrow 75.8 \% \rightarrow 76.2 \%$ ，相互銀行は $74.6 \% \rightarrow 76.7 \%$ あっった。相互銀行は 52 年以 前の数值が不明である。それゆえ，代わりに大蔵省の指導值を見ると，50年上期の $88.0 \%$ から 52 年下期には $78.0 \%$ に低下しており，50年代における改善の進展が推定される。50年代後半に ついては，都市銀行，地方銀行，相互銀行ともに悪化している。しかし，59年上期と60年上期 の值を比較すると，それぞれ，0.6\%，0.5\%，0.3\%ほど改善していた（61年度史料190〜 191 ・205頁)。この比率上昇は50年代における上述の検査官による「管理費用の増嵩」の指摘 の妥当性を示す。

次に，史料の制約もあり，50年代を通じて数值が採取できる地方銀行について，51年下期， 54年下期，60年下期における貸出証券利回り，預金コス卜，利鞘の推移を示す ${ }^{(50)}$ 。貸出証券 利回りは9.22\% $\rightarrow 8.84 \% \rightarrow 8.36 \%$, 預金コストは $7.37 \% \rightarrow 7.17 \% \rightarrow 6.73 \%$, 利鞘は $1.85 \% \rightarrow$ $1.67 \% \rightarrow 1.63 \%$ で推移していた。借手のコスト負担分を示す貸出証券利回りは50年代前半・後 半を通じて，ほほ同程度の減少を示す。預金コストは 50 年代前半には $0.2 \%$ の減少であったが， 後半になると $0.44 \%$ とほほ 2 倍の減少を示す。この結果，利鞘は 50 年代前半に大きく低下する ものの，後半には微減程度に止まる。預金コストには物件費などの経常支出の該当項目が含ま れる。それゆえ, 前述した経常収支率の低下を踏まえた場合, このような事実は, 金融検査と 行政指導を通じた個別金融機関経営における組織的管理体制の整備が，預金コストに示される 資金コストの圧縮に資する面があったことを示す。同時に，その結果，利鞘の推移に見られる ように，特に50年代後半において貸出証券利回りの低下にも耐えうる経営体制を構築すること を可能にした。このことが, 結果的に, 貸出証券利回りの低下に見られるように, 大蔵省の目 論見どおり，金融機関の利鞘を一定程度確保しつつも，借手の資金調達コストの低下に繫がっ たことは言うまでもない。

以上，50年代においては，行政指導にもかかわらず，組織的管理体制構築が本格化した中葉 から後半にかけての時期には比率の改善は殆んど見られなかった。しかしながら, 少なくとも 50 年代末から 60 年代初頭の時点になって, 一定程度, 指導の効果が顕れたと判断される。受検 銀行側が検査での指摘を曲がりなりにも容認した上で経営管理体制の改善に取り組んでいる事 実や，検查官の現場での指摘と『年報』における記述との間の整合性が少なからず見られる事 実から，『年報』における記述は少なからぬ妥当性があると判断される。 


\section{経営史学 第 43 巻第 4 号}

\section{8 結論}

1950年代における大蔵省の金融機関に対する行政指導は，通牒・通達を通じた「諸比率指 導」という，数量的なものであるとされてきた。しかし，本稿での検討の結果，特に経常収支 比率に関わるものでは，単なる数量的なものに止まらない，検査過程で経営内部に立ち入った 上で，人的資源の育成や経営の計画化も含む金融機関の組織的経営管理体制の充実・強化を図 ることも包含していたことが明らかになった。その際，特に，かかる指導の目的は，単なる経 営健全化や「金融正常化」には止まらない。大衆化への対応のほか，金融機関の組織効率の向 上に基づくコスト削減＝合理化による貸出利率低下を通じた，当時，国家的な重要課題であっ た，間接金融を主体とする日本経済の国際競争力強化が主要な目的であった。

次に検査過程での検查官の問題認識と指導の特徵である。再度の詳論はしないが，大蔵省金 融検査官の組織的経営管理体制に対する問題認識は業態毎に大きく異なる。しかし，特に都市 銀行を除く各業態の抱える経営管理問題として共通して認識されたのは，財務・貸出業務など 各行員の日常の作業も含む，「近代官僚制」的意味での組織的かつ専門的・「科学的」な経営管 理体制の欠如とその改善の必要性であった。このような必要性を踏まえて，トップから末端の 行員に至る，ある特定個人の意向や属人的資質に左右される金融機関経営の非合理性を，ルー ルと手続による没人格的・組織的かつ「近代官僚制」的で，なおかつ，コントローラー制度に 基づく計画的な経営に是正・平準化する方向で，単なる数值目標の提示には止まらない検査・ 指導を実施した。

このような問題認識と指導は，客観的にみてそれが適切かどうかは別として，地方銀行や相 互銀行といった中小企業金融機関については，少なくとも，経営組織整備の指針として基本的 に受容されていた。その結果，行員育成への着手の遅れも重要な要因と考えられる人的資源問 題による制約はあるものの，一定の改善を促進する性格を持っていたと判断される。この意味 で，少なくとも「経常収支率規制」に関しては，通牌・通達による目標値の提示と非「直接 的」指導のみではその達成は不可能であり, 金融検査と行政指導を通じた「直接的」指導によ つて補完されて，はじめてその効果を発揮したと言わねばならない。さらに，本稿の分析結果 は，戦後の護送船団方式と称される金融規制が，上述の無規律さの残存にもかかわらず，特に 相互銀行以下の金融機関を保護し続けた可能性を示唆する。

以上，1950年代における金融検查は，金融機関内部に直接立ち入った上で，組織整備を中心 とする経営の規律付けから人的資源の育成にまでも及ぶ包括的内容を持っており，資金供給先 である個別金融機関の効率化（「近代官僚制化」）を通じて日本の産業経済全般の効率化を企図 するものであった。この意味で，当該期の検查を通じた金融機関の業務改善，ひいては経営組 織の「近代官僚制」化の進展（前掲表 2 ）は，経営の効率性向上を目的に，トップのみなら ず，それまで「近代官僚制」的な形式合理性を十分に身に付けていなかった，末端の行員一人 一人の日常における作業レベルから根本的かつ重大な変化を促すものであった (51)。これに加 
えて，経営の規律付けを媒介にして，一見，矛盾するような個別金融機関の破綻回避を志向し た護送船団方式と経営の効率化とが結合していた。さらに，より長い夕イム・スパンで見る と，1950年代の状況は，両大戦間期以来の金融機関経営の「近代官僚制化」を促す検査と指導 の限界を受けて，行政側の対応のほかに，大衆化の進展に伴う事務量増大への対応という金融 機関経営上の必要性とも相俟って, その克服（「近代的経営」の実現）に向けての最終局面に 突入し，なおかつ大きく前進しようとした重要な時期であるとも位置づけられる。これらの諸 点は伊藤修氏ら先行研究では等閑視されており，特に強調しておきたい。

これらの諸点に，1950年代における大蔵省金融機関行政を基礎とする検査官の検査・指導の 意義と限界の特質を見出せる。

※本稿の作成に際して，史料提供をいただいた A 銀行，諸機関の皆様方，本稿の構想を得る 契機となった共著書の執筆過程で御指導と御助言を賜った，鈴木良隆先生，橋野知子氏には深 甚なる謝意を表す次第である。本稿は文部科学省科学研究費補助金若手研究 B（2002～2004年 度), 一橋大学大学院商学研究科21世紀 COE プログラムからの助成資金（2004 2007年度） による研究成果の一部である。

\section{注}

（1）「近代官僚制」という概念は Max Weber の議論を念頭においている。その定義は，職務の専門化と事務 処理手続きの形式合理化（規則化・没人格化）が大きく進展するとともに，階層的管理組織をもち長期的な 計画性に基づき最高管理者を中心とする管理者・管理組織層（企業で言えばコントローラー部門）が組織全 体の運営を統括すると概括される。紙幅の関係上, 詳細は省くが, このような議論はチャンドラーの「現代 企業」論とも相似しているとの指摘がある（鈴木良隆・橋野知子・白鳥圭志『MBAのための日本経営史』 有斐閣, 2007 年, 6-7頁)。チャンドラーの議論の対象は, 複数事業部と複数階層管理組織とをもつ製造業大 企業であり，本稿で扱う（中小）金融機関とは事業の在り方や管理組織の在り方が異なる点には注意する必 要はあるが，換言すれば，本稿で論じる金融機関の管理組織の「近代官僚制化」は，「現代企業」的管理組織 化とも言える。このような組織管理体制の整備は, 事務処理基準の明確化と省力化や経営行動の計画化（予 算統制）を通じた日常業務の規律付けと効率化をもたらすことにより，経費削減や経常収支率の改善に資す る側面がある（ほぼ同様な指摘は, 経営学者の P.ドラッカーや当時の実務家からも出されている。有賀裕子 訳『マネジメントII』日経 BP, 2008年, 第17・18章 ; 矢木五郎『銀行管理会計』全国地方銀行協会, 1956 年を参照)。この意味で，経営管理組織の「近代官僚制」化は，経常収支率の改善と関連を持つ。

（2）戦前・戦時期における銀行検查については, 先行研究の抱える問題点も含めて, 拙著『両大戦間期におけ る銀行合同政策の展開』八朔社, 2006 年, 第 $2 \cdot 3 \cdot 5$ 章, 終章を, 戦時下の銀行合同過程での組織的管理 体制の整備の遅延については，両羽銀行の事例を取扱った同「戦時体制下における地方銀行経営の変容」『社 会経済史学』第74卷 1 号, 2008年 6 月を参照。本稿の記述もこれらに基づく。さらに, 後述の埼玉銀行の事 例や地方銀行 A の事例も以下での議論を裏付ける。このほか，戦後復興期における金融機関の労働運動の激 しさは，地方金融史研究会編『続地方銀行史談』各号，全国地方銀行協会に掲載の各行頭取経験者のヒアリ ングも参照。 


\section{経営史学 第 43 巻第 4 号}

（3）伊藤修『日本型金融の歴史的構造』東京大学出版会，1995年，59・177-246頁；『昭和財政史 昭和27 48年』第10巻, 東洋経済新報社, 1991年, 第 1 章第 3 節, 第 2 章第 1 節。なお, 上記両書は内容的にも殆ど 相違はないので，その必要がある場合は，原則として『日本型金融の歴史的構造』のみを注記する。このほか, Takeo Hoshi and Anil Kashyap, Corporate Financing and Governance in Japan: The Road to the future, The MIT Press, 2001, Chapter 4, pp. 91-128; M. Aoki and H.Patick (eds.), The Japanese Main Bank System, Oxford University Press, 1994, Chapter 3, pp. 89-108（邦訳『日本のメインバンク・ システム』東洋経済新報社, 1996年, 第 3 章，105-127頁）では，戦後日本の金融システムの特徵として，大 蔵省を中心とする金融規制の重要性を強調しているが，その中核を担った検查や行政指導の内容に立ち入っ た検討をしていない。

(4) 注 (2) 文献を参照。

（5）伊牛田敏充「銀行経営史のフレイムワークについて」, 『地方金融史研究』第22号，1991年 3 月，64-77頁 では, 銀行経営の組織的管理体制の研究の必要性が提起されている。しかし, 検査など当局との関わりも含 めて，具体的な検討はされなかった。

（6）解説書は, 大蔵省銀行局検查部『新しい銀行検査法』大蔵財務協会，1951年，262-281・322頁。

（7）以下，大蔵省銀行局『銀行局金融年報』からの引用（記載内容は前年度分）は，本文中に「X年度史料」 と記載した上で，引用した文章がある頁数を示す。

（８）『山形銀行百年史』同行，1998年，402-403頁。戦前の検査と不良債権整理という意味での経営改善への誘 導手法は，拙著『両大戦間期における銀行合同政策の展開』第 2 ・ 3 章を参照。

（9）松沢卓二・岡崎哲二「日本型金融システムの大いなる功罪」，『週刊 東洋経済新報』，1995年 8 月 12 日〜 19日号，122頁。

（10）「山梨中央銀行 樋泉昌起氏との座談会」, 地方金融史研究会編『続地方銀行史談』第10集，全国地方銀行 協会，2002年 3 月，11頁。

（11）都市銀行は審査体制構築が中心であるが，『住友銀行史』同行，1955年，387頁，『三井銀行80年史』同行， 1957年，518頁，『第一銀行史』下巻，同行，1958年，522頁，『富士銀行80年史』同行，1960年，561頁，『三 菱銀行史』同行，1954年，469-471頁などを参照。杉浦勢之「戦後復興期の銀行・証券」，橋本寿朗編『日本 企業システムの戦後史』東京大学出版会，1995年，275-277頁も同様の事実を指摘している。個別地方銀行の 動向は，拙稿「戦時体制下における地方銀行経営の変容」を参照。

（12）全国地方銀行協会『地方銀行の本部機構について』同協会，1960年，11-14・44-45頁によれば，これらの 諸改革がその実現を目指す「近代的経営」の本質とは本部（コントローラー部門）を中心とする「計画的経 営」であった。その際, 事務処理基準の形式合理化とともに, その企画立案にあたる企画部門の設置が特に 重要であった。この記述が表 2 摘要欄の諸項目を選択した根拠である。

（13）例えば，『山形銀行百年史』，452頁や『西日本相互銀行十年史』同行，1954年，328頁ではこのような説明 がされている。

（14）注（2）のほか，地方金融史研究会編『戦後地方銀行史〔II〕』東洋経済新報社, 1992年; 後藤新一「銀 行」, 米川伸一ほか編『戦後日本経営史』東洋経済新報社，1991年，75-135頁などでも，本稿での検討対象は 扱われていない。

（15）この点は，各年度史料の各業態項目の冒頭の記載から判断できる。

（16）杉浦「戦後復興期の銀行・証券」，276-277頁も，本稿と同じ史料を用いて，メインバンク・システムの形 成との関係から貸出審查に問題を絞る形で検討している。なお，拙稿「大企業と金融システム」鈴木・橋 野・白鳥『MBAのための日本経営史』では，本稿では取り上げることのできなかった業態についての検査 
官の認識のみではあるが取り扱っている。

（17）伊藤『日本型金融の歴史的構造』，195-216頁。

（18）一例のみ挙げるが，関西経済連合会も1955年 3 月28日付けの文書で，日本製品の国際競争力強化のための 「物価の合理的な引下げ」のための政策的措置を要求している（「通貨金融政策に対する意見」，『日本証券史 資料』戦後編第 7 巻, 160-161頁)。その一環として「中小金融機関」の「経理監督を厳に」すること,「市中 金融機関の経営合理化」を含む「金利水準の引下げ」を掲げていた。

（19）『昭和財政史 昭和27-48年度』第10巻，184頁には地方銀行が「『長期経営計画』を自主的に策定」し， 「当局もこれを歓迎した」とある。しかし, 後述の A の事例も含めたとき, 当局がその策定と導入を促した のが実態であり，理解が転倒している。

（20）この点が1950年代における大蔵省の金融機関経営に関わる重要な政策理念であった点は，伊藤『日本型金 融の歴史的構造』, 217-226頁では指摘されていない。

（21）伊藤『日本型金融の歴史的構造』，196頁。

（22）詳細は，拙稿「戦後復興期における金融規制の再編成」，『地方金融史研究』第37号，2006年 3 月。

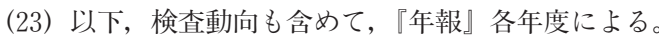

(24) 拙稿「金融規制の再編成」。

（25）当該年度の『年報』による。

（26）『年報』58年度版，392頁。

（27）以下，紙幅の都合上，詳細な引用はできないが，1950年代後半分や財務管理・貸出審查体制についての問 題も含めて, 『年報』に記載されている地方銀行が抱える経営の組織的管理上の問題点は, 1950年代に検查実 務を担当した末広隆介も実地検査の報告書に基づき指摘している（大蔵省銀行局検査部管理課指導係編『金 融検査の史料 第一篇』同係, 1967年 3 月，114-124頁)。ここから，当該引用部分は，執筆者によるバイア スは小さいと判断される。

（28）「山形銀行 丹羽厚悦氏との座談会」地方金融史研究会編『続地方銀行史談』第15集，全国地方銀行協会， 2007年 3 月，13-14頁。ただし，本事例は総務部内への設置である。

（29）紙幅の都合上，詳細な引用はできないが，以下，1950年代後半分や財務管理・貸出審查体制についての記 述も含めて, 『年報』に記載されている相互銀行の経営の組織的管理上の問題点は, 検査実務を検查した小林 春男も指摘している（『金融検查の史料 第一篇』，47-53頁）。ここから，当該引用部分は，執筆者によるバ イアスは小さいと判断される。このほか, 小林稿には相互銀行の業務上の諸問題の要因として, 無尽時代に は「無益契約を主体としたが故に, 契約自体において, 信用の授受両面の調整は自動的に営まれていた」こ とについての指摘がある。以下での地方銀行に比べての，相互銀行の組織的管理体制の形式合理化の進展度 合いの遅延という認識の背景には, 前身である無尽の特殊な経営の影響があることが予想される。しかし, 本稿ではこのことを十分に裏付けられなかった。今後の課題である。

（30）同様な事実は，福田久男検査部長（56年当時）も回顧している（大月高監修『実録戦後金融行政史』金融 財政事情研究会, 230頁)。

（31）例えば，兵庫相互銀行『兵庫相互銀行百年史』同行，1970年，255頁；広島相互銀行『広島相互銀行史』 同行，195頁などでも，事務処理手続きの形式合理化の未進展を自ら認めている。

（32）役員に関する問題は，東条猛猪銀行局長（55年 8 月から57年 6 月）の回顧にも見出せる（『実録戦後金融 行政史』, 546-551頁)。

（33）全国地方銀行協会編『検查から見た地方銀行経営』, 同協会, 1962年，125・126頁における清二彦検査官 の講演。 


\section{経営史学 第 43 巻第 4 号}

（34）このほかに大蔵省金融検査では粉飾預金も問題視された。もっとも，本稿は組織的管理体制構築問題と金 融検査との関係の検討を課題にしている関係上，本問題の検討は割愛する。

（35）『検查から見た地方銀行経営』，14・154頁。

（36）それぞれ，527・530頁，465頁，304・309頁，373・384頁。

（37）以下の議論は，本書の「はしがき」のほか，「第三 実地検査の方式」，「第五 内部牽制組織の要領」に 依拠した。

(38)『バンキング』第87号，1955年，118-125頁。

（39）拙著『両大戦間期における銀行合同政策の展開』，第 $2 \cdot 3$ 章。

（40）埼玉銀行『自昭和二十五年至昭和二十八年 支店長会議資料緅』合綴史料，平沼弥太郎「年頭の辞」， 1950年 1 月 27 日による。

（41）埼玉銀行調查課『埼玉銀行史料 特 No.1 号 平沼前頭取に聴く』，14-15頁。

（42）ただし，『平沼前頭取に聴く』によれば，経営状況が改善された後で，大蔵省金融検査官側から過度に厳 しい批判をしたことについての謝罪があったという。それゆえ，大蔵省側の指摘に行き過ぎた面があったと 見られることには留保が必要である。

（43）以下，A 所蔵の大蔵省金融検查関係史料による。なお，銀行名の特定を防止するために，検査の月日や預 金量の記載，史料原文の直接の引用などはしなかった。利用許可を受けた史料の範囲の制約から，史料の利 用箇所も組織管理体制の整備に関わるものに限定した。60年末の預金量等は全国地方銀行協会編『地方銀行 小史』, 同協会, 1961年, 別表 5 による。

（44）『弘前相互銀行史』同行，1974年，108-112頁。

（45）『山陽相互銀行50年のあゆみ』同行，1982年，144-145頁。

（46）『西京銀行60年史』同行，1992年，166-168頁。

（47）『松江相互銀行史』同行，1979年，238頁。

（48）新潟中央銀行『新潟中央銀行50年史』同行，1995年，165頁。

（49）とりあえず，このような推測の根拠として注29を参照。

（50）以下の数値は，『年報』 $1951 \cdot 1956 \cdot 1961$ 年度版より算出。

(51) このような銀行業務を巡る歴史的変化は，市原博「戦後日本のホワイトカラー」『経済学研究』（九州大 学) 第70巻 4 ・ 5 号, 2004年 1 月や, 渡辺峻「都市銀行における労務管理の発展」『経済経営論集』(龍谷大 学) 第30巻 1 号，1990年 8 月など銀行労働史研究でも問題にされていない。 